\title{
Recommendations of the AGG (Task Force for Obstetrics, Section Maternal Diseases) on the Management of Maternal Hepatitis B, C and D Infection in Pregnancy
}

\section{Empfehlungen der AGG (Arbeitsgemeinschaft Geburtshilfe, Sektion maternale Erkrankungen) zur maternalen Hepatitis-B-, -C- und -D-Infektion in der Schwangerschaft}

\section{(ㄷ) (1) (오 $\ominus$}

Authors

Maritta Kühnert ${ }^{1}$, Sven Kehl ${ }^{2}$, Ulrich Pecks ${ }^{3}$, Ute Margaretha Schäfer-Graf ${ }^{4}$, Tanja Groten ${ }^{5}$, Ralf Lothar Schild ${ }^{6}$, Dietmar Schlembach ${ }^{7}$, Markus Schmidt ${ }^{8}$, Amr Hamza9

Affiliations

1 Geburtshilfe, UFK Marburg, Marburg, Germany

2 Frauenklinik, Friedrich Alexander Universität ErlangenNürnberg, Erlangen, Germany

3 Frauenklinik, UKSH, Kiel, Germany

4 Klinik für Gynäkologie und Geburtshilfe, St. Joseph Krankenhaus, Berlin, Germany

5 Klinik für Frauenheilkunde und Geburtshilfe, Universitätsklinikum Jena, Jena, Germany

6 Klinik für Geburtshilfe und Perinatalmedizin, Diakovere Perinatalzentrum Hannover, Hannover, Germany

7 Klinik für Geburtsmedizin, Vivantes Klinikum NeuköllnBerlin, Berlin, Germany

8 Klinik für Frauenheilkunde und Geburtshilfe, Sana Kliniken Duisburg GmbH, Duisburg, Germany

9 Gynäkologie und Geburtshilfe, Universitätsklinikum des Saarlandes, Homburg, Germany

Key words

hepatitis, viral infection, pregnancy, delivery, puerperium

Schlüsselwörter

Hepatitis, Virusinfektion, Schwangerschaft, Geburt,

Wochenbett

received

26. 11.2020

accepted after revision

2. 12.2020

Bibliography

Geburtsh Frauenheilk 2021; 81: 390-397

DOI $10.1055 / \mathrm{a}-1330-7514$

ISSN $\quad 0016-5751$ (c) 2021. The Author(s).

This is an open access article published by Thieme under the terms of the Creative Commons Attribution-NonDerivative-NonCommercial-License, permitting copying and reproduction so long as the original work is given appropriate credit. Contents may not be used for commercial purposes, or adapted, remixed, transformed or built upon. (https://creativecommons.org/licenses/by-nc-nd/4.0/)

Georg Thieme Verlag KG, Rüdigerstraße 14,

70469 Stuttgart, Germany

Correspondence

Dr. Dietmar Schlembach

Vivantes Klinikum Neukölln-Berlin, Klinik für Geburtsmedizin

Rudower Straße 48, 12351 Berlin, Germany

dietmar.schlembach@vivantes.de

$\Theta$

Deutsche Version unter:

https://doi.org/10.1055/a-1330-7514

\section{ABSTRACT}

These statements and recommendations should provide appropriate information about maternal and fetal routes of infection, screening, detection of risk factors, diagnostic procedures, treatment, birth planning and peripartum and postpartum management of maternal hepatitis infection and offer pointers for prenatal counselling and routine clinical care on delivery wards.

\section{ZUSAMMENFASSUNG}

Diese Stellungnahmen und Empfehlungen dienen der Unterstützung in Schwangerenberatung und der täglichen Kreißsaalroutine betreffs maternaler und fetaler Ansteckungswege, dem Screening, der Erkennung von Risikofaktoren, der Diagnostik, der Therapie, der Geburtsplanung sowie dem periund postpartalen Management bei maternaler Hepatitisinfektion. 


\section{Recommendations on the Management of Maternal Hepatitis B Infection in Pregnancy}

\section{Introduction}

Maternal hepatitis B infection is a relevant viral disease in pregnancy. In $50 \%$ of cases, it results in perinatal infection, leading to chronic hepatitis B infection of children in up to $90 \%$ of cases if no adequate vaccination (active and passive) is carried out.

The aim of these recommendations is to provide a summary of the current body of knowledge and current recommendations on this topic.

\section{Screening}

\section{AGG RECOMMENDATION}

If a patient has risk factors for hepatitis, she should be tested for HBs antigen ( $\mathrm{HBsAg}$ ) at the start of pregnancy.

\section{AGG RECOMMENDATION}

If a patient has risk factors, the physician should consider carrying out testing to exclude other sexually transmissible infections.

If a patient has risk factors for hepatitis, she should be tested for $\mathrm{HBsAg}$ at the start of pregnancy and additional testing to exclude other sexually transmissible infections should also be considered.

Risk factors for hepatitis B infection include [1]:

- multiple sexual partners

- IV drug use (prior or current history of IV drug use)

- familial or sexual contact with hepatitis B carriers (vaccination recommended)

- children born to mothers infected with HBV

- patients and staff who work or live in closed institutions

- hemodialysis patients

- medical staff who come into contact with patient blood

- persons born in countries with high HBV seroprevalence

- persons who have had a blood transfusion

\section{AGG RECOMMENDATION}

If a patient has no risk factors, an $\mathrm{HBs}$ antigen ( $\mathrm{HBsAg}$ ) test should be carried out from the 32 nd week of gestation (GW).

Since 1994, the German Maternity Guidelines (Mutterschaftsrichtlinien) have also included regulations on routine screening for HBV infection during pregnancy using an $\mathrm{HBsAg}$ test and have suggested that testing for $\mathrm{HBs}$ antigen should be done in the third trimester (Mutterschaftsrichtlinien 1994; G-BA).

\section{Diagnostic approach}

\section{AGG RECOMMENDATION}

Testing for the following can be done to detect possible maternal infection with hepatitis B: $\mathrm{HBsAg}$, anti-HBc, anti-HBs, IgM anti-HBc.

- Table 1 shows how the respective findings should be interpreted.

HBs antigen (HBsAg) is a protein on the surface of the hepatitis B virus. Detection of HBsAg is evidence of acute or chronic infection with hepatitis $B$.

The immune system produces $\mathrm{HBc}$ antibodies (anti-HBc) to combat the virus. Evidence of anti-HBc indicates that the patient has either been infected with hepatitis B or is currently still infected with the virus.

HBs antibodies (anti-HBs) are antibodies produced by the immune system against $\mathrm{HBsAg}$ which are produced during recovery or successful vaccination and they provide immune protection.

- Table 1 Interpretation of hepatitis B serology test results [1]

\begin{tabular}{|c|c|c|}
\hline Serology & Findings & Interpretation \\
\hline $\begin{array}{l}\mathrm{HBsAg} \\
\text { anti-HB } \\
\text { anti-HBs }\end{array}$ & $\begin{array}{l}\text { negative } \\
\text { negative } \\
\text { negative }\end{array}$ & At risk of $\mathrm{HBV}$ infection \\
\hline $\begin{array}{l}\mathrm{HBsAg} \\
\text { anti-HBC } \\
\text { anti-HBs }\end{array}$ & $\begin{array}{l}\text { negative } \\
\text { positive } \\
\text { positive }\end{array}$ & Immune due to infection \\
\hline $\begin{array}{l}\mathrm{HBsAg} \\
\text { anti-HBc } \\
\text { anti-HBs (> } 100 \mathrm{IU} / \mathrm{L})\end{array}$ & $\begin{array}{l}\text { negative } \\
\text { negative } \\
\text { positive }\end{array}$ & $\begin{array}{l}\text { Immune following vacci- } \\
\text { nation against hepatitis } B\end{array}$ \\
\hline $\begin{array}{l}\mathrm{HBsAg} \\
\text { anti-HBC } \\
\text { IgM anti-HBC } \\
\text { anti-HBs }\end{array}$ & $\begin{array}{l}\text { positive } \\
\text { positive } \\
\text { positive } \\
\text { negative }\end{array}$ & Acutely infectious \\
\hline $\begin{array}{l}\mathrm{HBsAg} \\
\text { anti-HBC } \\
\text { IgM anti-HBC } \\
\text { anti-HBs }\end{array}$ & $\begin{array}{l}\text { positive } \\
\text { positive } \\
\text { negative } \\
\text { negative }\end{array}$ & Chronic infection \\
\hline $\begin{array}{l}\mathrm{HBsAg} \\
\text { anti-HBc } \\
\text { anti-HBs }\end{array}$ & $\begin{array}{l}\text { negative } \\
\text { positive } \\
\text { negative }\end{array}$ & $\begin{array}{l}\text { Unclear, possible } \\
\text { variants: } \\
\text { 1. previous infection } \\
\text { from which the pa- } \\
\text { tient has recovered } \\
\text { 2. false-positive anti- } \\
\text { HBc (risk of infection) } \\
\text { 3. chronic infection } \\
\text { 4. recovery period } \\
\text { following acute } \\
\text { infection }\end{array}$ \\
\hline
\end{tabular}




\section{AGG RECOMMENDATION}

In pregnant women infected with hepatitis $\mathrm{B}$, the $\mathrm{HBV}$ viral load (HBV DNA) should be determined in the 3rd trimester of pregnancy (> $24+0$ week of gestation).

As drug therapy may be necessary during pregnancy for women infected with hepatitis B, the HBV viral load (HBV DNA) should be determined in the 3rd trimester of pregnancy $(>24+0$ week of gestation). The comparability of laboratory values and the inconsistencies in reporting the results of quantitative tests are wellknown problems. In addition to the standard way of reporting results $(\mathrm{IU} / \mathrm{ml})$ proposed by the WHO, findings may also be reported as copies/ml. A simple non-test-dependent conversion of the results using a uniform conversion factor is not possible. The laboratory responsible for evaluating the test should be able to provide the respective conversion if required.

\section{Maternal hepatitis B infection and other diagnostic measures}

\section{AGG RECOMMENDATION}

If there is a suspicion of chromosomal abnormality, an invasive diagnostic investigation (chorionic villus sampling or amniocentesis) can be carried out in pregnant women with hepatitis B infection, but only after careful consideration of all factors involved.

It is important to inform the patient that the risk of maternalfetal transmission increases in cases with high viral load.

There is a $50 \%$ risk of intrauterine infection with amniocentesis, while the risk without amniocentesis is about 4\% (OR 21.3; $p=0.06$ ). Because of the limited evidence, an invasive diagnostic procedure (chorionic villus sampling or amniocentesis) can be offered to pregnant women infected with hepatitis B if there are medical indications for the procedure. The risk of maternal-fetal transmission increases in cases with high viral load (> 7 log $10 \mathrm{IU} /$ $\mathrm{ml})[2]$.

\section{Drug therapy}

\section{AGG RECOMMENDATION}

Maternal antiviral therapy may be considered for pregnant women with hepatitis B and high viral load to reduce the risk of intrauterine fetal infection.

Maternal antiviral therapy may be considered for pregnant women with hepatitis B and high viral load > 6-8 log 10 copies/ $\mathrm{ml}$ to reduce the risk of intrauterine fetal infection. The viral load at delivery is $3 \%$ with maternal drug treatment and $18 \%$ without treatment [3].
An elective caesarean section be may considered in cases with a high viral load who did not have antiviral drug treatment to reduce the risk of intrauterine fetal infection.

\section{AGG STATEMENT}

Tenofovir is recommended as the first-line antiviral therapy to treat pregnant women with hepatitis B infection (high viral load, fulminant and acute disease).

The administration of tenofovir by a hepatologist is recommended as the first-line therapy to treat pregnant women with hepatitis B infection, high viral load and/or fulminant and acute disease. Tenofovir can suppress the virus below the limits of detection and is associated with low development of resistance [4]. Treatment with tenofovir started at 24-32 weeks of gestation and continued up until 4 weeks post partum resulted in a significant reduction of mother-to-child transmission of hepatitis $B$ virus by $80 \%$ [5].

\section{Planning the birth}

\section{AGG STATEMENT}

Maternal hepatitis B infection is not an indication for routine caesarean section.

Caesarean section to reduce vertical transmission in cases with maternal hepatitis B infection is not evidence-based and should therefore not be routinely carried out [6].

\section{Peripartum management}

\section{AGG RECOMMENDATION}

Invasive procedures during the birth should be avoided where possible.

The main causes of peripartum infection of the neonate with hepatitis $B$ are contact with infectious vaginal blood and secretions and invasive procedures during delivery (placement of a fetal scalp electrode, fetal blood analysis, episiotomy, and surgical vaginal delivery) [1]. Invasive procedures during delivery should therefore be avoided where possible.

\section{Postpartum management}

\section{AGG RECOMMENDATION}

Active and passive HBV vaccination of the neonate should be carried out up to 12 hours post partum if the mother is $\mathrm{HBsAg}$-positive or if her HBsAg status is unknown. 
The perinatal rate of transmission has significantly decreased in the last 20 years [7]. Active and passive postnatal HBV vaccination up to 12 hours post partum has contributed significantly to this reduction in transmission rates: the rate of chronic HBV infections has decreased from $10 \%$ to $1 \%$ within the space of 10 years [8]. Moreover, the number of pediatric hepatocellular carcinomas decreased from 0.7 to 0.36 per 100000 [4, 9].

\section{AGG RECOMMENDATION}

Children who were born to mothers infected with hepatitis B virus and who were actively and passively vaccinated can be breastfed.

There is no difference in infection rates between breastfed and formula-fed vaccinated infants of mothers with HBV infection [10].

\section{Recommendations for Maternal Hepatitis C Infection in Pregnancy}

\section{Introduction}

Around $8 \%$ of pregnant women are infected with hepatitis $C$ virus (HCV); $75 \%$ of all of these infections are asymptomatic. Chronic infections are almost always asymptomatic. Around $15-30 \%$ of these infected persons will go on to develop cirrhosis within 20 years if they do not receive treatment and $27 \%$ of them will develop hepatocellular carcinoma within 10 years [11,12]. Comorbidities such as intrahepatic cholestasis (normally 0.2-2.5\%) are 20 times more common in combination with HCV infection [13]. These guidelines aim to provide a condensed overview of the current state of knowledge and the most recent recommendations on this topic.

\section{Screening}

\section{AGG RECOMMENDATION}

Patients with risk factors should be tested for hepatitis $C$ virus infection, irrespective of the gestational age of their fetus.

Women with the following risk factors should undergo prenatal screening for hepatitis C virus (HCV) [14]:

- women who have injected illegal drugs (even if it happened only once)

- users of intranasal illegal drugs

- women who require long-term hemodialysis

- women who have undergone percutaneous/parenteral procedures in dubious conditions (tattoos in non-licensed facilities or medical procedures in premises not subjected to hygiene inspections)

- women who received transfusions or organ transplants prior to July 1982
- women who received clotting factors manufactured prior to 1987

- women who received blood products whose donors later tested positive for HCV

- women who have spent time in prison

- women with sexually transmissible diseases including HIV

- women with unexplained chronic liver disease (including persistently elevated ALT)

\section{AGG RECOMMENDATION}

Pregnant women with risk factors for hepatitis $C$ virus infection should be tested for anti-HCV antibodies. If the test is negative, it should be repeated again at a later stage in cases with persistent or newly occurring risk factors (e.g., persistent or new drug use).

\section{AGG RECOMMENDATION}

HCV-positive pregnant women should be tested for sexually transmissible diseases (HIV, syphilis, gonorrhea, chlamydia, HBV).

HCV-positive women who are also infected with other sexually transmissible infections have a higher HCV RNA titer and a 2times higher risk of vertical transmission [15]. The HCV transmission rate of children born to mothers who take intravenous drugs is also higher.

\section{Diagnostic procedure}

\section{AGG STATEMENT}

The diagnosis of hepatitis $C$ virus infection is based on detection of anti-HCV antibodies and HCV RNA.

The diagnosis of hepatitis $C$ virus infection is based on detection of anti-HCV antibodies (which develop 2-6 months after exposure to disease and persist for the rest of the patient's life) and HCV RNA (= viremia, active infection 1-3 months after exposure) [12, 16]. - Table 2 provides a useful overview on how to interpret hepatitis $C$ serological test results based on the recommendations of the CDC [14].

\section{Maternal hepatitis $C$ infection and other diagnostic procedures}

\section{AGG RECOMMENDATION}

Amniocentesis can be carried out in selected cases if an invasive prenatal diagnostic procedure is necessary. Chorionic villus sampling should not be carried out. 
- Table 2 Interpretation of hepatitis C serological test results.

\begin{tabular}{|l|l|l|}
\hline HCV RNA/antigen & $\begin{array}{l}\text { HCV antibodies } \\
\text { (IgG+IgM) }\end{array}$ & Infection status \\
\hline negative & negative & risk of infection \\
\hline positive & negative & acute infection \\
\hline positive & dubious & acute infection \\
\hline positive & positive & $\begin{array}{l}\text { acute or chronic } \\
\text { infection }\end{array}$ \\
\hline $\begin{array}{l}\text { negative (with } \\
\text { a sensitivity } \\
\text { of } 10-25 \text { IE/ml) }\end{array}$ & positive & $\begin{array}{l}\text { healed (spontane- } \\
\text { ously or at least six } \\
\text { months after the } \\
\text { end of treatment) }\end{array}$ \\
\hline
\end{tabular}

The risk of vertical transmission after amniocentesis is low, but there are no valid data on transmission following chorionic villus sampling [17]. Amniocentesis can therefore be carried out if an invasive prenatal diagnostic procedure is necessary, while chorionic villus sampling should not be carried out.

\section{Drug therapy}

\section{AGG STATEMENT}

Antiviral HCV therapy is contraindicated during pregnancy.

\section{AGG RECOMMENDATION}

DAA (= direct-acting antiviral) regimens should only be administered in the context of clinical trials or only post partum (no testing during pregnancy).

The aim of treatment is to achieve SVR (= sustained virological response). HCV RNA will only be negative 12-24 weeks after completing therapy. If SVR is achieved, then the HCV infection is cured. Fibrosis in cases with cirrhosis decreases and there are fewer complications such as liver failure, HCC or portal hypertension [18].

There are no data on the impact of a DAA regimen during pregnancy [19].

Interferon regimens are no longer recommended. DAA regimens achieve SVR rates of $>90 \%$ and are tolerated better, and treatment times are shorter [20].

\section{AGG RECOMMENDATION}

HCV-positive pregnant women with a combination of risk factors should be vaccinated against hepatitis $B$ virus (passively and actively) and hepatitis A virus, even during pregnancy.
Hepatitis A infection can exacerbate the liver damage occurring with HCV infection [11]. Vaccination against hepatitis A and hepatitis $B$ virus is therefore generally recommended because of the increased risk that these infections may take a serious course in women infected with $\mathrm{HCV}$; the vaccinations against hepatitis $\mathrm{A}$ and $B$ viruses consist of inactivated vaccines $[1,18]$.

\section{Planning the birth}

\section{AGG STATEMENT}

Maternal hepatitis $C$ infection is not an indication for routine caesarean section.

\section{AGG RECOMMENDATION}

Placement of a fetal scalp electrode for internal fetal monitoring and fetal blood analysis should be avoided in HCV-positive patients. Rupture of membranes must not be managed expectantly.

Vertical transmission occurs in $30-50 \%$ of cases up until week $39+0$ of gestation; the rest occurs afterwards or during delivery [21].

During the birth, there is a higher risk of transmission from contact with maternal blood if fetal blood analysis is carried out or a scalp electrode is placed on the fetus [1]. Similarly, prolonged rupture of membranes in HCV-positive women is significantly associated with an increased risk of HCV transmission [22]. Expectant management of early rupture of membranes should therefore be avoided [20,23].

The risk of vertical transmission increases with HIV co-infection (6 vs. 11\%) [15]. Moreover, a high viral load is correlated with a higher risk of transmission [22-27].

Data on the benefit of caesarean section to reduce vertical transmission compared to vaginal birth in women with hepatitis $\mathrm{C}$ infection are lacking [28]. Caesarean section for hepatitis $\mathrm{C}$ infection is therefore not recommended.

\section{Postpartum management}

\section{AGG RECOMMENDATION}

HCV-positive patients should be encouraged to breastfeed their infant.

Breastfeeding infants born to HCV-infected mothers does not increase maternal-fetal transmission rates. There is an increased risk of infection when women have HCV/HIV co-infection, have bleeding or traumatised nipples or consume illegal drugs $[12,20]$.

Anti-HCV antibodies can pass from the mother to the fetus through the placenta during pregnancy. Evidence of anti-HCV antibodies in neonatal blood shortly after birth is therefore not an indication of neonatal infection. The infants are considered 
HCV-positive if two tests carried out after the first month of life or later are HCV RNA positive or if anti-HCV antibodies are detected 24 months after the birth [22].

\section{Recommendations for Maternal Hepatitis D Infection in Pregnancy}

\section{Introduction}

HDV (hepatitis D virus) is a natural satellite virus of HBV (hepatitis $B$ virus). Transmission is parenteral, and the release and infectiousness of HDV depends on the presence of HBV infection. HDV infection always hinges on HBV infection, i.e., it only occurs in HBsAg-positive patients. There are 2 forms of HDV infection: simultaneous infection with HBV and HDV, and HDV superinfection of carriers of HBV. Both forms can be acute or chronic [29].

In western Europe, co-infection with HDV is found in $5-12 \%$ of patients with chronic hepatitis B infection $[29,30]$.

\section{Screening}

\section{AGG RECOMMENDATION}

Hepatitis D virus superinfection must be excluded in all patients with hepatitis B (irrespective of whether they are newly diagnosed or were not tested for HDV despite being known to have hepatitis B infection or are experiencing exacerbation of chronic hepatitis B infection).

Diagnostic procedures to check for HDV superinfection are mandatory for all patients with HBV infection, as the lethality of HDV infection is 10 -times higher than that of HBV infection by itself [29].

\section{Diagnostic procedure}

\section{AGG STATEMENT}

Using IgM antibodies to differentiate between acute and chronic infection will not provide specific findings. This also applies when attempting to differentiate between persistent and healed hepatitis $D$, which is why confirmation based on HDV RNA is better.

Evidence of anti-HDV antibodies is obtained by immunoassay, while evidence of its infectiousness (= viral evidence) is based on HDV RNA obtained using RT-PCR [31]. PCR detection can be difficult due to the high variability of the virus. Special laboratories can provide quantitative evidence [32-34].

Using IgM antibodies to differentiate between acute and chronic infection does not provide very specific findings [35]; it is similarly difficult to differentiate between persistent and healed hepatitis D; confirmation based on HDV RNA is better for this.
This also applies to therapeutic monitoring: monitoring based on quantification of HDV RNA should be done before and during treatment of HDV infection with interferon alpha.

HDV RNA persists for at least 6 months in cases with chronic HDV infection [35].

\section{Maternal hepatitis delta infection and other diagnostic procedures}

\section{AGG STATEMENT}

There are no data on the benefits of invasive prenatal diagnostic procedures (amniocentesis, chorionic villus sampling).

There are no evidence-based data on the risk of transmission from invasive prenatal diagnostic procedures carried out in mothers with HDV infection.

\section{Drug therapy}

\section{AGG STATEMENT}

There are no data on HDV therapy in pregnancy.

While various data on hepatitis $C$ infection and possible therapies during pregnancy are available, there are no data on HDV therapy in pregnancy.

Vaccination against hepatitis A and $B$ viruses is generally recommended in cases with acute hepatitis because of the increased risk for a severe course of infection to prevent exacerbation of liver damage $[1,18]$.

\section{Planning the birth}

\section{AGG STATEMENT}

Maternal infection with hepatitis $\mathrm{D}$ is not an indication for routine caesarean section.

\section{AGG RECOMMENDATION}

Internal fetal monitoring, prolonged rupture of membranes and episiotomy should be avoided during birth in HDVpositive patients, and expectant management of rupture of membranes should similarly be avoided (same approach as for HCV infection because no data are available for HDV).

Maternal infection with hepatitis D virus is not an indication for routine caesarean section. Because of the potential risk of transmission to the neonate, internal fetal monitoring, prolonged rupture of membranes and episiotomy during the birth should be avoided in HDV-positive mothers. Similarly, expectant manage- 
ment of early rupture of membranes should also be avoided (cf. the approach used for HCV infection) [1, 22].

\section{Peripartum management}

\section{AGG STATEMENT}

Maternal-fetal transmission is theoretically possible. However, there are no data available on this.

\section{Postpartum management}

\section{AGG STATEMENT}

There are no data on the transmission of HDV during breastfeeding.

\section{AGG STATEMENT}

Hepatitis D infection can be prevented by postnatal vaccination of the neonate against hepatitis $B$ virus.

There are no evidence-based data on the transmission of HDV during breastfeeding. HDV infection can be prevented by postnatal vaccination of the neonate against HBV. HBV vaccination is therefore the best form of protection, and the risk of HBV or HDV infection during breastfeeding is negligible $[12,29,36]$.

\section{Conflict of Interest}

The authors declare that they have no conflict of interest.

\section{References}

[1] Society for Maternal-Fetal Medicine (SMFM); Dionne-Odom J, Tita ATN, Silverman NS. \#38: Hepatitis B in pregnancy screening, treatment, and prevention of vertical transmission. Am J Obstet Gynecol 2016; 214: 614

[2] Yi W, Pan CQ, Hao J et al. Risk of vertical transmission of hepatitis B after amniocentesis in HBs antigen-positive mothers. J Hepatol 2014; 60: 523-529

[3] Greenup AJ, Tan PK, Nguyen V et al. Efficacy and safety of tenofovir disoproxil fumarate in pregnancy to prevent perinatal transmission of hepatitis B virus. J Hepatol 2014; 61; 502-507

[4] Chang MH, Chen C], Lai MS et al. Universal hepatitis B vaccination in Taiwan and the incidence of hepatocellular carcinoma in children. Taiwan Childhood Hepatoma Study Group. N Engl J Med 1997; 336; 1855-1859

[5] Brown RS jr., Verna EC, Pereira MR et al. Hepatitis B virus and human immunodeficiency virus drugs in pregnancy: findings from the Antiretroviral Pregnancy Registry. J Hepatol 2012; 57; 953-959

[6] Yang J, Zeng XM, Men YL et al. Elective caesarean section versus vaginal delivery for preventing mother to child transmission of hepatitis B virusa systematic review. Virol J 2008; 5: 100
[7] Mast EE, Weinbaum CM, Fiore AE et al.; Advisory Committee on Immunization Practices (ACIP) Centers for Disease Control and Prevention (CDC). A comprehensive immunization strategy to eliminate transmission of hepatitis B virus infection in the United States: recommendations of the Advisory Committee on Immunization Practices (ACIP) Part II: immunization of adults. MMWR Recomm Rep 2006; 55: 1-33; quiz CE1CE4

[8] Chen HL, Chang MH, Ni YH et al. Seroepidemiology of hepatitis B virus infection in children: Ten years of mass vaccination in Taiwan. JAMA 1996; 276: 906-908

[9] Robert Koch-Institut. Impfempfehlungen der Ständigen Impfkommission (Stiko), Stand 2019/20. Epidemiol Bull 2019; 34: 313-352

[10] Hill JB, Sheffield JS, Kim M] et al. Risk of hepatitis B transmission in breastfed infants of chronic hepatitis B carriers. Obstet Gynecol 2002; 99: 1049-1052

[11] American College of Obstetricians and Gynecologists. ACOG Practice Bulletin No. 86: Viral hepatitis in pregnancy. Obstet Gynecol 2007; 110: 941-556

[12] World Health Organization. Guidelines for the screening, care, and treatment of persons with chronic hepatitis $C$ infection. Accessed July 12 , 2017 at: http://www.who.int/hiv/pub/hepatitis/hepatitis-c-guidelines/ en

[13] Wijarnpreecha K, Thongprayoon C, Sanguankeo A et al. Hepatitis C infection and intrahepatic cholestasis of pregnancy: A systematic review and meta-analysis. Clin Res Hepatol Gastroenterol 2017; 41: 39-45

[14] Society for Maternal-Fetal Medicine (SMFM). Electronic address: pubs@smfm.org; Hughes BL, Page CM, Kuller JA. Hepatitis C in pregnancy: screening, treatment, and management. Am J Obstet Gynecol 2017; 217: B2-B12

[15] Benova L, Mohamoud YA, Calvert $C$ et al. Vertical transmission of hepatitis C virus: systematic review and meta-analysis. Clin Infect Dis 2014; 59: 765-773

[16] Maheshwari A, Thuluvath PJ. Management of acute hepatitis C. Clin Liver Dis 2010; 14: 169-176

[17] Gagnon A, Davies G, Wilson RD; Genetics Committee. Prenatal invasive procedures in women with hepatitis $B$, hepatitis $C$, and/or human immunodeficiency virus infections. J Obstet Gynaecol Can 2014; 36: 648-655

[18] Kim DK, Riley LE, Harriman KH et al. Advisory Committee on Immunization Practices Recommended Immunization Schedule for Adults Aged 19 Years or Older - United States, 2017. MMWR Morb Mortal Wkly Rep 2017; 66: 136-138

[19] Spera AM, Eldin TK, Tosone G et al. Antiviral therapy for hepatitis C: Has anything changed for pregnant/lactating women? World J Hepatol 2016; 8: 557-565

[20] Sarrazin C, Zimmermann T, Berg T et al. S3-Leitlinie „Prophylaxe, Diagnostik und Therapie der Hepatitis-C-Virus (HCV) -Infektion “ AWMFRegister-Nr.: 021/012. Z Gastroenterol 2018; 56: 756-838. doi:10.1055/a-0599-1320

[21] Mok J, Pembrey L, Tovo PA et al. When does mother to child transmission of hepatitis C virus occur? Arch Dis Child Fetal Neonatal Ed 2005; 90: F156-F160

[22] Mast EE, Hwang LY, Seto DS et al. Risk factors for perinatal transmission of hepatitis $\mathrm{C}$ virus (HCV) and the natural history of HCV infection acquired in infancy. J Infect Dis 2005; 192: 1880-1889

[23] Checa Cabot CA, Stoszek SK, Quarleri J et al.; NICHD International Site Development Initiative Perinatal/Longitudinal Study in Latin American Countries Study Group. Mother-to-Child Transmission of Hepatitis C Virus (HCV) Among HIV/HCV-Coinfected Women. J Pediatric Infect Dis Soc 2013; 2: 126-135

[24] Snijdewind IJ, Smit C, Schutten M et al. Low mother-to-child-transmission rate of Hepatitis C virus in CART treated HIV-1 infected mothers. J Clin Virol 2015; 68: 11-15 
[25] European Paediatric Hepatitis C Virus Network. A significant sex-but not elective cesarean section-effect on mother-to-child transmission of hepatitis C virus infection. J Infect Dis 2005; 192: 1872-1879

[26] Ceci O, Margiotta M, Marello F et al. Vertical transmission of hepatitis C virus in a cohort of 2,447 HIV-seronegative pregnant women: a 24 month prospective study. J Pediatr Gastroenterol Nutr 2001; 33: 570 575

[27] Ohto $\mathrm{H}$, Terazawa S, Sasaki $\mathrm{N}$ et al. Transmission of hepatitis $\mathrm{C}$ virus from mothers to infants. The Vertical Transmission of Hepatitis C Virus Collaborative Study Group. N Engl J Med 1994; 330: 744-750

[28] McIntyre PG, Tosh K, McGuire W. Caesarean section versus vaginal delivery for preventing mother to infant hepatitis $C$ virus transmission. Cochrane Database Syst Rev 2006; (4): CD005546

[29] Wedemeyer H, Heidrich B, Manns MP. Hepatitis D virus infection-not a vanishing disease in Europe! Hepatology 2007; 45: 1331-1332; author reply $1332-1333$

[30] Wedemeyer H, Manns MP. Epidemiology, pathogenesis and management of hepatitis D: update and challenges ahead. Nat Rev Gastroenterol Hepatol 2010; 7: 31-40
[31] Shattock AG, Morris MC. Evaluation of commercial enzyme immunoassays for detection of hepatitis delta antigen and anti-hepatitis delta virus (HDV) and immunoglobulin M anti-HDV antibodies. J Clin Microbiol 1991; 29: 1873-1876

[32] Mederacke I, Bremer B, Heidrich B et al. Establishment of a novel quantitative hepatitis D virus (HDV) RNA assay using the Cobas TaqMan platform to study HDV RNA kinetics. J Clin Microbiol 2010; 48: 2022-2029

[33] Castelnau C, Le Gal F, Ripault MP et al. Efficacy of peginterferon alpha-2b in chronic hepatitis delta: relevance of quantitative RT-PCR for followup. Hepatology 2006; 44: 728-735

[34] Le Gal F, Gordien E, Affolabi D et al. Quantification of hepatitis delta virus RNA in serum by consensus real-time PCR indicates different patterns of virological response to interferon therapy in chronically infected patients. J Clin Microbiol 2005; 43: 2363-2369

[35] Lau JY, Smith HM, Chaggar K et al. Significance of IgM anti-hepatitis D virus (HDV) in chronic HDV infection. J Med Virol 1991; 33: 273-276. doi:10.1002/jmv.1890330412

[36] Seto MTN, Cheung KW, Hung IFN. Management of viral hepatitis A, C, D and E in pregnancy. Best Pract Res Clin Obstet Gynaecol 2020; 68: 4453. doi:10.1016/bpobgyn.2020.03.009 